\title{
KINERJA APARAT PENGAWAS INTERN PEMERINTAH INSPEKTORAT \\ PROVINSI KALIMANTAN TENGAH DALAM MELAKSANAKAN FUNGSI PENGAWASAN DAN PEMBINAAN (Studi Dalam Aspek Sarana Prasarana)
}

\author{
Kristian Lirit
}

\begin{abstract}
ABSTRAK
Penelitian ini bertujuan untuk mengetahui kinerja aparat pengawas intern pemerintah inspektorat provinsi Kalimantan tengah. Indikator yang digunakan dalam mengukur kinerja aparat pengawas intern pemerintah inspektorat provinsi Kalimantan tengah, dalam penelitian ini yaitu inputs (masukan), Process (proses), output (keluaran), Outcomes (hasil), Benefits (manfaat) dan Impacts (dampak). Penelitian ini dilakukan dengan menggunakan metodelogi kualitatif deskriftif dengan melakukan wawancara kepada pegawai inspektorat provinsi Kalimantan tengah selaku aparat pengawas intern pemerintah. Data yang diperoleh kemudian diolah dengan langkah reduksi, penyajian data dan penarikan kesimpulan. Jumlah informan yang di wawancara ada 6 orang dan juga dilakukan wawawancara dengan 3 informan dari SKPD yang berbeda. Berdasarkan hasil penelitian menegnai kinerja aparat pengawas intern pemerintah inspektorat provinsi Kalimantan tengah sudah dilakukan dengan baik dan sesuai dengan ketentuan pengawasan dilihat dari input (masukan), process (proses), output (keluaran), outcomes (hasil), benefits (manfaat), dan impacts (dampak). Faktor yang mempengaruhi kinerja aparat pengawas intern pemerintah dalam melaksanakan pengawasan dan pembinaan meliputi keterbatasan SDM, anggaran, tugas pengawasan yang kompleks dan luas.
\end{abstract}

Kata Kunci: Kinerja, aparat, inspektorat, pengawasan, pembinaan, Kalimantan Tengah

\section{PENDAHULUAN}

\section{Latar Belakang Masalah}

Pada umumnya dapat dikatakan, bahwa pengawasan terhadap segala kegiatan terhadap Pemerintahan Daerah termasuk keputusan Kepala Daerah, merupakan suatu akibat mutlak dari adanya Negara kesatuan. Di dalam Negara kesatuan kita tidak mengenal bagian yang lepas dari atau sejajar dengan Negara, tidak mungkin pula ada Negara di dalam Negara. Dalam penyelenggaraan tugas pemerintahan pada umumnya haruslah diusahakan adanya keserasian atau harmonisai antara tindakan pusat atau negara dengan tindakan daerah. Mengenai penyelenggaraan Pemerintah di Daerah ialah kontrol terhadap penyelenggaraan pemerintahan di daerah atau jalannya Pemerintahan Daerah maupun terhadap unsur-unsur pelaksananya adalah hasil yang telah dicapai.

Untuk menerapkan pengkajian yang nyata terhadap penyelengaraan-penyelenggaraan Pemerintah di Daerah maupun para pelaksanaannya diperlukan penilaian bilamana hasil yang telah dicapai dapat dinilai dan bila perlu ambil langkah yang korektif. Bilamana semua fungsi dan kebijakan dalam penyelenggaraan pemerintahan di daerah yang telah ditentukan atau tidak menyimpang pelaksanaannya dari aturan yang telah ditetapkan maka kontrol atau pengawasan akan mudah dilakukan, bagaimanapun juga berhubung dengan keadaan penyelanggaraan Pemerintahan di Daerah maka betepa pentingnya pengawasan bagi penyelenggaraan Pemerintah 
di Daerah yang makin luas dan kompleks. Ada beberapa bentuk dan sasaran pengawasan yang semuanya dapat digolongkan seperti pengawasan yang dilakukkan oleh Kepala Wilayah, Bimbingan dan Pengawasan terhadap penyelenggaraan Pemerintahan Daerah di samping menjadi tugas Pemerintah Daerah adalah menjadi tugas Kepala Wilayah, Bimbingan dan Pengawasan itu harus selalu dilakukan sesuai dengan ketentuan-ketentuan yang berlaku dalam fungsi pengawasan. Dalam manajemen organisasi termasuk organisasi di Pemerintahan Daerah fungsi pengawasan (controling) adalah salah satu unsur penting untuk melaksanakan pengawasan di Pemerintah Daerah maka di bentuk lembaga Inspektorat Provinsi Kalimantan Tengah yang berperan sebagai Aparat Pengawas Interen Pemerintah (APIP). APIP diharapkan menjadi agen perubahan yang dapat menciptakan nilai tambah pada produk atau layanan Instansi Pemerintah. APIP sebagai Pengawas Interen Pemerintah merupakan salah satu unsur manajemen Pemerintah yang penting dalam rangka mewujudkan Kepemerintahan yang baik (good governance) yang mengarah kepada pemerintahan/birokrasi yang bersih (clean governance). Inspektorat Provinsi Kalimantan Tengah dalam melaksanakan pengawasan mengutamakan fungsi konsultan (consulting) dan pemberi keyakinan yang memadai dan mutu (quality assurance) atas efisiensi dan efektifitas manajemen risikodan proses tata kelola penyelengaraan Pemerintah yang diawasi. Dalam suatu instansi atau organisasi pemerintah maupun swasta sangat diperlukan kinerja pegawai, karena kinerja pegawai sangat menentukan tercapainya tujuan organisasi atau instansi tersebut.

Adapun pengertian kinerja yaitu hasil kerja yang di hasilkan oleh seseorang karyawan atau pegawai diartikan untuk mencapai tujuan yang diharapkan. Kinerja adalah gambaran tingkat pencapaian pelaksanaan suatu kegiatan/program/kebijakan dalam mewujudkan sasaran, tujuan, misi dan visi yang tertuang dalam perumusan strategis suatu instansi. Kinerja sering dimaknai sebagai prestasi kerja yang dicapai organisasi dalam periode tertentu. Prestasi kerja dimaksud berkaitan dengan efektivitas operasional organisasi baik berkenaan dengan aspek manejerial maupun ekonomis operasional, melalui informasi kinerja organisasi (Pemerintah) dapat mengetahui secara jujur dan objektif sampai sejauh mana tingkat keberhasilan bahkan tingkat kegagalannya.

Pada kenyataannya urusan dan tanggung jawab Pemerintah Daerah dari tahun ketahun semakin meningkat, baik dalam penyelenggaraan pemerintahan, pembangunan dan pembinaan kemasyarakatan. Sejalan dengan meningkatnya urusan Pemerintah Daerah tersebut terjadi pula peningkatan jumlah dan jenis barang yang dikelola oleh Pemerintah Daerah yang merupakan salah satu unsur penting dalam menyelenggarakan Pemerintahan dan pembangunan serta pembinaan kemasyarakatan. Pengelolan Barang Daerah selama ini telah berjalan namun belum terlaksana sebagaimana mestinya yang diharapkan untuk mencapai daya guna hasil yang maksimal, sehingga diperlukan peraturan-peraturan sebagai pedoman dalam pelaksanaan pengelolaan barang Daerah. Barang adalah semua kekayaan Pemerintah yang dimiliki maupun yang dikuasai yang berwujud, baik yang bergerak maupun tidak bergerak besrta bagian-bagiannya ataupun yang merupakan satuan tertentu yang dinilai, dihitung, ditukar atau ditimbang. Yang dimaksud dengan barang daerah adalah Asset Daerah berupa bergerak maupun tidak bergerak yang dimiliki/dikuasai Pemerintah Daerah yang sebagian atau seluruhnya dibeli atas beban APBD serta pengelolan lain yang sah yang terdiri dari:

1. Barang yang dimiliki/dikuasai oleh Pemerintah Daerah dan barang-barang yang diserahkan penggunaannya/pemakaiannya kepada Instansi/Lembaga Pemerintah Daerah maupun kepada Instansi/Lembaga Lainya berdasarkan ketentuan yang berlaku.

2. Barang-barang yang dimiliki/dikuasai oleh Perusahaan Daerah dan Bank Pembangunan Daerah yang berstatus kekayaan daerah yang dipisahkan adalah dalam arti wewenang 
pengelolannya oleh Perusahaan Daerah/Bank Pembangunan Daerah dan dana anggarannya dibebankan pada dana anggaran Perusahaan Daerah/Bank Pembangunan Daerah.

Pengelolaan barang adalah rangkaian kegiatan atau tindakan terhadap Pemerintah Daerah yang meliputi perencanaan dan penetuan kebutuhan, penganggaran, standarisasi barang dan harga, pengadaan, penyimpanan, penyaluran, inventarisasi, penggunaan, pengendalian, pemeliharaan penghapusan dan lain-lain. Dalam hal ini untu pengelolaan asset daerah yang sepertinya mudah ternyata banyak mengalami masalah, mulai dari ada barang inventasi yang tidak dicatat, pengapusan barang yang rusak belum diusulkan, pembelian barang yang diluar ketentuan, sehingga hal ini yang perlu dilakukan pengawasan dan Pembinaan atas penyelenggaraan pemerintahan daerah. Upaya yang dilakukan untuk mewujudkan terciptanya tujuan penyelengaraan otonomi daerah, adapun pengawasan atas penyelenggaraan pemerintahan daerah adalah proses kegiatan yang ditujukan untuk menjamin agar Pemerintah Daerah berjalan sesuai dengan rencana dan ketentuan peraturan perundang-undangan yang berlaku. kita ketahui bahwa pengawasan itu sangat penting untuk dilakukan, tanpa adanya pengawasan mungkin Pemerintahan di Daerah tidak akan berjalan dengan baik bahkan bisa menyimpang dari jalurnya serta tanpa adanya pengawasan akan banyak kesalahan-kesalahan yang dilakukan oleh Pemerintahan di Daerah dalam menyelenggarakan urusan Pemerintahan Daerah, bisa dibayangkan jika tidak ada yang mengawas jalanya Pemerintahan di Daerah, terjadinya kesalahan dalam penyelenggaraan urusan Pemerintahan daerah bukan karena faktor kesengajaan, tapi karena ketidaktahuan mereka dalam melaksanakannya, hal inilah yang perlu dilakukan pengawasan dan pembinaan mengenai urusan penyelenggaraan pemerintahan di daerah dan betepa pentingnya pengawasan.

Seperti fungsi Inspektorat melaukan pengawasan dan pembinaan, dalam hal ini ada beberapa aspek pengawasan yang dilakukan oleh inspektorat di antaranya aspek pengelolaan Sarana Prasarana, penggunaan Sarana dan prasarana yang digunakan oleh Pemerintahan Daerah, dalam hal ini pengeloaan Sarana Prasarana sangat penting untuk dilakukan pengawasan dan pembinaan, baik dalam penggunaannya atau dalam memelihara serta dalam pengadaannya, seperti pengadaan barang dan jasa. Hal ini tentunya sangat berpengaruh dalam pelaksanaan kerja, apabila Sarana dan Prasarana yang digunakan tidak sesuai dengan kebutuhan kerja, hal ini yang perlu dilakukan pengawasan dan pembinaan supaya tidak menyimpang dan sesuai sebagaimana mestinya. Itulah sebabnya mengapa pengawasan sangat penting untuk dilakukan.

Berdasarkan pelaksanaan pengawasan dan pembinaan pada Inspektorat Provini Kalimantan Tengah tersebut diatas, maka keberadaan Badan Pengawas Daerah merupakan Instansi vertikal yang ditugaskan di Provinsi Kalimantan Tengah sebagai Aparat Pengawasan Interen Pemerintah. Namun permasalahan yang terjadi bahwa pelaksanaan fungsi pengawasan belum dilakukan secara efektif, alasannya karena pelaksanaan pemeriksaan kinerja Pemerintah selama ini belum sesuai dengan yang direncanakan, dimana dapat dilihat pelaksanaan pengawasan tidak tepat waktu, hal ini disebabkan karena adanya keterlambatan dalam pengumpulan data yang digunakan dalam pemeriksaan serta jumlah Auditor yang belum mencukupi dalam memenuhi tugas secara optimal dan komprehensif dalam melakukan pemeriksaan sehingga memakan waktu yang cukup lama di tambah lagi kurangnya fasilitas yang memadai dalam melakukan pemeriksaan, hal tersebut sangat tidak menunjang untuk melakukan pengawasan secara maksimal atau dengan kata lain tidak sepenuhnya yang dimkasud sebagaimana mestinya menjalankan fungsi pengawasan.

Berdasarkan latar belakang diatas maka penulis tertarik untuk melakukan penelitian yang berjudul ;"Kinerja Aparat Pengawas Intern Pemerintah Inspektorat Provinsi Kalimantan Tengah Dalam Melaksanakan Fungsi Pengawasan Dan Pembinaan” 


\section{RumusanMasalah}

Adapun rumusan masalahnya adalah sebagai berikut :

a. Bagaimanakah kinerja Aparat Pengawas Interen Pemerintah Inspektorat Provinsi Kalimantan Tengah dalam melaksanakan fungsi Pengawasan dan Pembinaan terhadap pengelolaan Sarana Prasarana (aset) di Provinsi Kalimantan Tengah

b. Faktor-faktor apa saja yang mempengaruhi kinerja Aparat Pengawas Intern Pemerintah Inspektorat Provinsi Kalimantan Tengah dalam melaksanakan fungsi pengawasan dan pembinaan.

\section{LANDASAN TEORI}

\section{Konsepsi Kinerja}

Kinerja dalam sebuah organisasi merupakan salah satu unsur yang tidak dapat dipisahkan dalam suatu lembaga organisasi, baik itu lembaga pemerintahan maupun lembaga swasta. Kinerja berasal dari kata Job Performance atau Actual Performance yang merupakan prestasi kerja atau prestasi sesungguhnya yang dicapai seseorang. Kinerja adalah hasil atau tingkat keberhasilan seseorang secara keseluruhan selama periode tertentu di dalam melaksanakan tugas dibandingkan dengan berbagai kemungkinan, seperti standar hasil kerja, target atau sasaran atau kriteria yang telah ditentukan terlebih dahulu dan telah disepakati bersama.

Pengertian tersebut dapat disimpulkan bahwa kinerja sumber daya manusia adalah prestasi kerja atau hasil kerja (output) baik kualitas maupun kuantitas yang dicapai SDM persatuan periode waktu dalam melaksanakan tugas kerjanya sesuai dengan tanggung jawab yang diberikan kepadanya. Kinerja adalah hasil atau tingkat keberhasilan seseorang secara keseluruhan selama periode tertentu di dalam melaksanakan tugas.

pengertian kinerja menurut para ahli :

Menurut Donnelly, Gibson and Ivancevich(1994). Kinerja merujuk kepada tingkat keberhasilan dalam melaksanakan tugas serta kemampuan untuk mencapai tujuan yang telah ditetapkan. Kinerja dinyatakan baik dan sukses jika tujuan yang diinginkan dapat tercapai dengan baik.

\section{Indikator Kinerja}

Dalam sistem Akuntabilitas Kinerja Instansi Pemerintah (AKIP) indikator kinerja di kelompokan kedalam 6 (enam) kelompok indikator kinerja yaitu:

a. Inputs (masukan)

Indikator masukan, adalah segala sesuatu yang digunakan dalam pelaksanaan kegiatan agar menghasilkan keluaran. Indikator ini dapat berupa dana, personil, yang terlibat dalam pelaksanaan kegiatan, data/informasi, kebijakan/peraturan perundangan dan sebagainya.

b. Process (proses)

Indikator proses, adalah berbagai aktivitas yang menunjukan upaya yang dilakukan dalam rangka mengolah masukan menjadi keluaran. Indikator ini menggambarkan pelaksanaan pengolahan masukan menjadi keluara.

icapai dalam 


\section{d. Outcomes (hasil)}

Indikator hasil, adalah hasil nyata yang diperoleh dari keluaran. Indikator hasil mencerminkan berfungsinya keluaran pada jangka waktu menengah.

e. Benefits (manfaat)

Indikator manfaat, adalah manfaat yang diperoleh dari hasil (outcomes) suatu kegiatan. Manfaat akan dapat dirasakan dalam jangka waktu menengah dan panjang.

f. Impacts (dampak)

Indikator dampak, adalah pengaruh/akibat yang ditimbulkan oleh manfaat dari suatu kegiatan, baik dampak negatif maupun dampak positif.

\section{Faktor - Faktor yang Mempengaruhi Kinerja}

Menurut A. Dale Timple terdapat beberapa faktor dalam kinerja yang terdiri dari faktor internal dan faktor eksternal. Berdasarkan hal tersebut maka akan dijelaskan sebagai berikut:

Faktor-faktor kinerja terdiri dari faktorinternal dan faktor eksternal,

a. faktor internal (disposisional) yaitu faktor yang berhubungan dengan sifat-sifat seseorang.

b. faktor eksternal yaitu faktor-faktor yang mempengaruhi kinerja seseorang yang berasal dari lingkungan. Seperti perilaku, sikap, dan tindakan-tindakan rekan kerja, bawahan atau pimpinan, fasilitas kerja dan iklim organisasi (Dalam Mangkunegara, 2009:15). ${ }^{1}$

Faktor internal dan faktor eksternal di atas merupakan jenis-jenis atribusi yang mempengaruhi kinerja seseorang. Jenis-jenis atribusi yang dibuat oleh para pegawai memiliki sejumlah akibat psikologis dan berdasarkan kepada tindakan. Seorang pegawai yang mengangap kinerjanya baik berasal dari faktor-faktor internal seperti kemampuan atau upaya. Misalnya, kinerja seseorang baik disebabkan karena mempunyai kemampuan tinggi dan seseorang itu mempunyai tipe pekerja keras. Sedangkan seseorang mempunyai kinerja jelek disebabkan orang tersebut mempunyai kemampuan rendah dan orang tersebut tidak memiliki upaya-upaya untuk memperbaiki kemampuannya.

\section{Pengertian Pengawasan dan Pembinaan}

\section{Pengawasan}

Pengawasan atas penyelenggaraan Pemerintahan Daerah adalah proses kegiatan yang ditujukan untuk menjamin agar Pemerintah Daerah berjalan sesuai dengan rencana dan ketentuan peraturan perundang-undangan yang berlaku. Pengawasan atas penyelenggaraan Pemerintahan Daerah dilaksanakan oleh Pemerintah yang meliputi:

1. Pengawasan atas pelaksanaan urusan Pemerintahan di Daerah

2. Pengawasan terhadap peraturan daerah dan peraturan Kepala Daerah

\section{Pembinaan}

Pembinaan atas penyelenggaraan Pemerintah Daerah adalah adalah upaya yang dilakukan untuk mewujudkan terciptanya tujuan penyelenggaraan Otonomi Daerah.Pembinaan atas penyelanggaraan Pemerintahan Daerah dilaksanakan oleh Pemerintah dan atau Gubernur selaku Wakil Pemerintah di Daerah.

\footnotetext{
${ }^{1}$ A. Dale TimpleDalam Mangkunegara, 2009:15. http://elib.unikom.ac.id/download 21 november 2014
} 


\section{Jenis-jenis Pengawasan}

Dalam suatu Negara terlebih-lebih yang sedang berkembang atau membangun, maka kontrol atau pengawasan sangat penting dan beragam, baik secara vertikal maupun secara horizontal. Oleh karena itu untuk mencapai tujuan negara atau organisasi maka dalam pengawasan ini dapat pula diklasifikasikan sebagai berikut.

1. Pengawasan interen

Pengawasan interen adalah pengawasan yang dilakukan oleh aparat dalam organisasi itu sendiri. Pada dasarnya pengawasan harus dilakukan oleh pucuk pimpinan sendiri. Akan tetapi, dalam prakteknya hal ini selalu tidak mungkin terjadi. Oleh karena itu setiap pimpinan unit dalam organisasi pada dasarnya berkewajiban membantu pucuk pimpinan untuk membantu pucuk pimpinan mengadakan pengawasan secara fungsional sesuai dengan bidang tugasnya masing-masing. Pengawasan sebagai fungsi organik, buitin pada setiap jabatan pimpinan mereka harus melakukan pengawasan terhadap keseluruh aparat dalam organisasi itu, seperti oleh Inspektorat Jenderal dalam Departemen.

2. Pengawasan Ekstern

Pengawasan Ekstern adalah pengawasan yang dilakukan oleh aparat luar organisasi itu sendiri, seperti halnya pengawasan dibidang keuangan oleh Badan Pemeriksa Keuangan sepanjang meliputi seluruh Aparat Negara dan Direktorat Jenderal pengawasan keuangan negara terhadap departemen dan instansi pemerintah lain.

\section{Pengawasan Preventif}

Pengawasan preventif, sasaran pengawasan ini adalah Peraturan Daerah dan Keputusan Kepala Daerah untuk meneliti apakah peraturan dan Keputusan Kepala Daerah bertentangan peraturan perundang-undangan yang lebih tinggi atau dengan kepentingan umum atau urusan yang bersangkutan telah diatur dalam peraturan yang lebih tinggi.

\section{Pengawasan Represif}

Pengawasan represif adalah sasaran pengawasan ini adalah peraturan daerah dan keputusan Kepala Daerah. Sepintas lalu pengawasan ini diragukan keperluannya karena sebelum peraturan daerah atau keputusan Kepala Daerah itu berlaku terlebih dahulu disaring oleh pengawasan preventif. Maksud dari pengawasan ini adalah untuk meneliti apakah peraturan daerah dan keputusan Kepala Daerah bertentangan dengan peraturan perundang-undangan yang lebih tinggi atau dengan kepetingan umum atau urusan yang bersangkutan telah diatur oleh peraturan perundang-undangan yang lebih tinggi.

\section{Tujuan Pengawasan}

Pengawasan ini bertujuan untuk mengetahui apakah pelaksanaan sesuai dengan rencana yang telah ditetapkan ataukah tidak, dan untuk mengetahui kesulitan-kesulitan apa saja yang dijumpai oleh para pelaksana agar kemudian diambil langkah-langkah perbaikan. Dengan adanya pengawasan maka tugas pelaksanaan dapatlah diperingan oleh karena para pelaksana tidak mungkin dapat melihat kemungkinan-kemungkinan kesalahan yang diperbuatnya dalam kesibukan sehari-hari. Pengawasan bukanlah untuk mencari kesalahan akan tetapi justru untuk memperbaiki kesalahan.

\section{METODE PENELITIAN}

Jenis penelitian yang digunakan untuk mengkaji permasalahan yang diteliti dalam karya ilmiah ini adalah penelitian kualitatif Deskriptif. Menurut Bodgan dan Taylor (1975 : 5) Metode 
penelitian kualitatif merupakan prosedur penelitian yang menghasilkan data deskriptif berupa kata - kata tertulis atau lisan dari orang - orang dan perilaku yang dapat diamati. Menurut mereka pendekatan ini di arahkan pada latar dan inidividu tersebut secara holistik (utuh). Metode kualitatif berusaha mengkapkan berbagai keunikan yang terdapat dalam individu dan kelompok, masyarakat atau organisasi dalam kehidupan sehari - hari secara menyeluruh, rinci, dalam dan dapat dipertanggungjawabkan secara ilmiah (Miles and Huberman 1994 : 6 - 7).

\section{HASIL DAN PEMBAHASAN}

Berdasarkan hasil penelitian yang dilakukan mengenai Kinerja aparat pengawas intern pemerintah ispektorat provinsi Kalimantan tengah dalam menjalankan fungsi pengawasan dan pembinaan, berdasrkan indikator kinerja bahwa kinerja inspektorat dalam melaksankan fungsi pengawasan dan pembinaan khususnya dalam aspek sarana prasarana, sudah dilakukan dengan baik berdasarkan ketentuan peraturan perundang-undangan dan ketentuan pengawasan.

\section{KESIMPULAN DAN SARAN}

\section{Kesimpulan}

Setelah melakukan penelitian tentang Kinerja Aparat Pengawas Intern Pemerintah Inspektorat Provinsi Kalimantan Tengah Dalam Melaksanakan Fungsi Pengawasan Dan Pembinaan khususnya dalam aspek sarana prasarana, sudah diuraikan didepan, dan dapat diberikan kesimpulan berdasarkan indikator kinerja. Jadi dapat disimpulkan bahwa kinerja inspektorat provinsi Kalimantan tengah dalam melaksanakan fungsi pengawasan dan pembinaan dalam aspek sarana prasarana sudah dilakukan dengan baik, berdasarkan peraturan dan undangundang serta ketentuan yang berlaku.

Adapun faktor-faktor yang mempengaruhi kinerja Aparat Pengawas Intern Pemerintah Inspektorat Provinsi Kalimantan Tengah dalam melaksanakan fungsi pengawasan dan pembinaan khususnya dalam aspek sarana prasarana yaitu

$>$ dilihat dari faktor internal: seperti keterbatasan SDM, anggaran

$>$ dilihat dari faktor Eksternal: tugas pengawasan yang komleks dan luas serta transportasi dalam melakukan pengawasan dan pembinaan.

\section{Saran}

Berdasarkan hasil penelitian dan pembahasan yang dilakukan menegnai Kinerja Aparat Pengawas Intern Pemerintah Inspektorat Provinsi Kalimantan Tengah dalam melaksanakan fungsi pengawasan dan pembinaan khususnya dalam aspek sarana prasarana, penulis menemukan beberapa aspek penting yang dinilai perlu untuk diperhatikan lagi, khususnya yang menjadi kendala dalam melaksanakan pengawasan dan pembinaan, untuk itu melalui skripsi ini penulis memberikan saran sebagai berikut:

1. Diharapkan bagi pemerintah untuk bisa memperhatikan kendala dalam melaksanakan pengawasan dan pembinaan, seperti keterbatasan SDM dalam melaksanakan pengawasan dan pembianaan.

2. Serta pemerintah memperhatikan anggaran dan transportasi untuk melakukan pengawasan, supaya pengawasan ini bisa menjadi lebih baik lagi.

\section{DAFTAR PUSTAKA}

Adisasmita Rahardjo. 2011. Manajemen Pemerintah Daearah. Yogyakarta:Graha Ilmu.

Basrowi, Suwandi. 2008. Memahami Penelitan Kualitatif. Jakarta: Rineka Cipta 
Dale, A Timple Dalam Mangkunegara, 2009:15. http://elib.unikom.ac.id/download 21 november 2014

Diponingrat, Sunarjo. 1957. Undang-Undang Tentang Pokok-pokok Pemerintahan Daerah. Jakarta: Gunung Agung

Donnelly, Gibson and Ivancevich.1994. Apa Itu Kerja. Maruasas Sianturi. Kompasina Edukasi( Internet)

Hennry Simamora (Hennry dalam Mangkunegara) 2009:14)http://elib.unikom.ac.id/download 21 november 2014

Melati, Irma Ika. 2011. Skripsi Analisis Faktor - Faktor yang Mempengaruhi Kinerja Pegawai.Fakultas Ekonomi Universitas Dipenogoro: Semarang: Undip

Ninik, Sunindhia. 1987. Kepala Daerah dan Pengawasan Dari Pusat. Jakarta: PT. Bina Aksara

Pedoman Penulisan Skripsi. 2013. Edisi Pertama. Universitas Palangka Raya. Fakultas Ilmu Sosial dan Politik

Peraturan Daerah Provinsi Kalimantan Tengah Nomor 4 Tahun 2012, Perubahan atas Peraturan Daerah Nomor 7 Tahun 2008, Tentang Organisasi dan Tata Kerja Inspektorat, Badan Perencanaan Pembangunan dan Lembaga Teknis Daerah Provinsi Kalimantan Tengah

Peraturan Daerah Provinsi Kalimantan Tengah Nomor 7 Tahun 2008 Tentang Organisasi Tata Kerja Inspektorat, Badan Perencanaa Pembangunan Daerah Dan Lembaga Teknis Daerah Provinsi Kalimantan Tengah

Peraturan Gubernur Kalimantan Tengah Nomor 22 Tahun 2013. Tentang Tugas Pokok Fungsi dan Uraian Tugas Inspektorat Provinsi Kalimantan Tengah.

Peraturan Gubernur Kalimantan Tengah. 2008. Tentang Tugas Pokok dan Fungsi Inspektorat Provinsi Kalimanatan Tengah Tentang Tugas dan Fungsi Inspektorat Provinsi Kalimantan Tengah

Peraturan Menteri Dalam Negeri Nomor 17 Tahun 2007 Tentang Pedoman Teknis Pengelolaan Barang Milik Daerah

Peraturan Menteri Dalam Negeri Nomor 23 Tahun 2007 Tentang Pedoman Tata Cara Pengawasan Atas Penyelenggaraan Pemerintahan Daerah

Peraturan Menteri Dalam Negeri Nomor 51 Tahun 2010 Tentang Pedoman Pengawasan Penyelenggaraan Pemerintahan Daerah Tahun 2011

Peraturan Menteri Dalam Negeri Republik Indonesia Nomor 60 Tahun 2013. Tentang Kebijakan Pengawasaan atas Penyelengaraan Pemerintahan Daerah Tahun 2014.

Peraturan Pemerintah Republik Indonesia Nomor 79 Tahun 2005 Tentang Pedoman Pengawasan Penyelenggaraan Pemerintahan Daerah

Rivai,Vethzal \& basri. 2005. Performance Appraisal: Sistem Yang Tepat Untuk Menilai Kinerja Karyawan dan Meningkatkan Daya Saing Perusahaan. Jakarta : PT. RajaGfindoPersada.

Robbins, Stepen P. 2006. Perilaku Organisasi, Jakarta: PT Indeks Kelompok Gramedia.

Sedarmayanti. Good Governance (Pemerintahan Yang Baik) Bagian kedua. Bandung: Mandar Maju. 
Sianturui Maruasas. 2013. Kompasiana Edukasi. Apa Itu Kinerja.Widyaiswara PPPPTK Medan (www.Pengertian kinerja / Internet)

Suripto, C, Soleh. Menilai Kinerja Pemerintah Daerah. FM Fokusmedia

Syahfiie Inu, Kencana. 2004. Birokkrasi Pemerintahan Indonesia. Bandung: Mandar Maju

Trimartono. Pengertian kinerja BAB II.jbptunikompp-gdl-trimartono-24331-2-babii_d-x (hasil internet)

Undang-Undang Republik Indonesia Nomor 23 tahun 2014 Tentang Pemerintahan Daerah

Wicaksono, K, Widya. 2006. Administrasi dan Birokrasi Pemerintah. Yogyakarta: Graha Ilmu

Zulkarnain. 2012. Skripsi Pengaruh Kinerja Pegawai Terhadap Efektifitas Organisasi Di Kantor Kecamatan Kelapa Dua Kabupaten Tanggerang.Universitas Sultan Ageng Tirtayasa. Fakultas Ilmu Sosial Dan Ilmu Politik 